\title{
Bidrag til Haderslev Amts Historie og Beskrivelse.
}

Af P. Lauridsen.

\section{Om Adel og adeligt Bondegods i Amtet samt om Kongernes Kjob af samme.}

Den oprindelige Adel i Nordslesvig var Hærmændsslægter af sønclerjysk eller fælles-dansk Oprindelse. I det I4de Aarhundrede, da Arveadelen dannede sig, træffe vi her som $i$ den øvrige Del af Landet kun danske Ætter. Det er Navne som Skrum, Emmiksen, Friis, Vinter, Sture, Juul, Tinhuus, Holk, Knudsen, Rosenkrans, Abildgaard o. m. a., der bæres af denne Adel. Men under de sidste svage Herskere' af Abels Stamme tilrev de holstenske Grever sig en overvældende Magt i Landet, fra 1325 til 1375, i 50 Aar $f_{ø r}$ Hertugættens endelige Udslukkelse, kæmpede de med liet stadige Maal for Øje at sætte sig i endelig Besiddelse af Sønderjylland, og i denne Kamp støttedes de af clen krigerigske og frugtbare holstenske Adel, der sammen med dem trængte frem over Ejderen. Ogsaa i andre Henseender beyunstigedes denne Fremtrængen. 1313 maatte Erik Menved opgive Krongodset, det saakaldte Konnungelef, i 
Sønderjylland og fire Aar senere ligeledes sin Ret til at vælge Hærmænd i Landet nd over det Antal, han alt havde.") Begge disse Indrømmelser havde højst skadelige Følger. De danske Hærmænd vare ilde sete af Herskerne, deres undergivne bleve Gjenstand for Villkarrligheder, og under de følgende Tiders Trængsler søgte mange af disse Næand til Kongeriget. Allerede derved blev der Plads for indvandrede tyske Slægter, men da Grev Gert 1325 forlenedes med Hertngdømmet, benyttede han og hans nærmeste Efterfølgere ligefrem det danske Krongods til at skaffe den indvandrede holstenske Adel et solidt Fodfreste i Landet. De Riddlergodser, der oprettedes fra 1313 til 1459, danne Kjærnen i de nuwærende adelige Distrikter i Hertugdømmet (27 $\square$ Mil), og de findes netop fortrinsvis i de Egne, hvor det danske Krongods laa: i Angel, Sransø og Danske Skov. I Midten af det 14de Aarhundrede optræder den holstenske Adel allerede med overvældende Magt helt op til Kongeaaen. Som en krigerisk Højadel, der er nøje knyttet til de fremmede Herskere og for at tøjle den vrangvillige $\mathrm{Be}$ folkning forlenet med de fjendtlige Landskaber, stiller den de indfødte Atter i Skygge, og sætter sig ved Kjøb eller Arv. i delvis Besiddelse af deres Ejendonime.' Kong Christian I.'s stadige Finansnød tvang ham til at gjøre deme Adel endnu større Indrømmelşer, og ved hans Død var hele Amtet ude af Kronens Haand, idet den vestlige Del: Gram, Fros, Kalvslund og Hvidding Herreder, styredes af Herrerne paa Torning, og Resten var pantsat til Dronning Dorthea eller ejedes af den stedlige Adel.

Ikke des mindre holdt en stor Del af de gamle Slægter

*) Artikel af Velschouw i Hist. Tidsskr. 
sig her lige op til 1580-88, og den haderslevske Adel vedblev derfor at have et meget broget Udseende: holstenske, sønderjyske og kongerigske $\mathbb{E t t e r}$ levede Side om Side; Emmikser'ne, Tirhuser'ne, Lindenov'erne, Munk'erne, Ulfeld'erne o.a. bevarede deres Fædreejendomme lige indtil det store Udlijøb fandt Sted, og Amtet rensedes for Adel, som maaske intet andet $\mathrm{i}$ de danske Stater. - Allerede efter Chr. I. indtraadte en stærk Reaktion imod Adelen, idet de efterfølgende Konger og Fyrster havde større Evne til at værne om deres egne og det menjge Folks Interesser. Paa en Gang lagde Kong Hans fire Herreder med Torning Slot til sin Andel af Hertugdømmerne, og nogle faa Aar senere erlivervede Frederik I. Eis bølg a a ${ }^{\prime}$ d med et meget betydeligt Tilliggende af Bøndergods, ligesom Hertug Hans clen ældre med Kraft traadte op imod Adelsherrernes Gridskherl efter Gods og Jord. Det egentlige Hovedslag førtes rog af Kong Frederik II., idet han fira 1580-88 udkjøbte næsten hele Adelen i Amtet, og Formynderregeringen og Christian IV. fuldstændiggjorte dette saaledes, at der ikke blev andet Adelsgods tilbage, end Gram og de Rantzauske Gaarde Høgsbro og Vesterbæk i Hvidding Herred. Men skjøndt Adelen saaledes forsvandt tidlig fra Amtet, har den ikke desmindre øvet en meget betydelig Indflydelse paa dets ældre Laudboforhold; som et fremmed Reagens i en Befollning af frie Bønder er clet for en stor Del clen, der har fremlraldt Frestevæsenet i Nordslesvig, og for en rigtig Forstanelse af Agrarudviklingen er det derfor nødvendigt at begynde med en Fremstilling af Adelens Gods og dettes Kjøb af Kongerne. Det er dette, der vil blive forsogt i det følgende. 
Tørning. I Middelalderen fandtes tre Hovedborge $\bar{i}$ Sønderjylland: Tørning i Barvedsyssel, Lille-Tønder i Ellumsyssel og Gottorp i Istedsyssel. Fra Tørning styredes hele Nordslesvig mellem Løgumkloster og Kolding. Det ældste bevarede Dokument, hvori Tørning forekommer, er et Pantebrev fra Grev Gert af Holsten til den holstenske Ridder Henneke v.Hummersbïttel fra 1331.*), Greven pantsætter Hindsgavl med det halve Fyen, men, i Fald dette Pant skulde blive ham fravristet, giver han Ridderen yderligere Sikkerhed i "Tørninghus med det hele Fogderi“ (altsaa vel Barved Syssel) og - stadig under samme Forudsætning - endvidere Underpant i Pløen i Holsten. Tølning var dog allerede dengang pantsat til Grevens vigtigste Hjælpere Hartvig og Nikolaus Reventlau, men bvorlænge disse have beholdt det, vides ikke. Tyve Aar senere var Tørning dog gaaet helt. ud af Statens Hænder, thi da ejedes det af den sydslesvigske Ridder Claus Lembek d. æ., uden at det kan oplyses, hvorledes han har erhvervet det. Allerede dengang synes der at have ligget et stort Antal Bønder til Borgen, og disse forøgedes i høj Grad senere, idet Hertug Gerhard 1394 pantsatte hele Gram Herred paa Livstid til Sønnen Henneke Lembek. Derved kom denne i Besiddelse af næsten kongelig Magt over Omegnen. Alle Kronens Rettigheder og Skatter, hele Retsplejen i alle Instanser, alle Domæner, Agre, Enge, Skove, Søer, intet undtagen (uden Patronatsret og Leding) overdrages ham, og i 100 Aar sad Herrerne paa Tørning som Fyrster i Nordslesvig. Ganske vist solgte Cl a us Le m bek

*) Original i Gemein. Archiv, XII. 4. Voss' Excerpt, Bind C. (XXIII, 2.) Huitfeldt. I. S. 455. 
d. y. 1407 Trøjborg og Skinkelborg Len*) til Dronning Margrethe, hrorved en stor Del Adelsgods atter kom ind under Kronen, men 1421 modtog han — som til Gjengjæld - Frøs, Hvidding og Kalvslund Herreder som Pantelen af de holstenske Grever, og hans Svigersøn og Arvtager Benedikt $v$. Ahlefeldt og dennes Sønner beholdt dette store Len i 73 Aar, ja, 1460 overdrog Kong Christian I. ham he le Gram Herred til fri Ejend om, og Bønderne bleve saaledes alle gjorte til Adelsbønder, til Tørningtjenere. Som det gik i Haderslev Amt, saaledes gik det mange andre Steder, men efter Hertugdømmernes Deling mellem Hans og Frederik 1490 bestræbte disse sig med Held paa at indløse Panterne og indskrænke Adelens Magt.

1494 kjøbte Kong Hañs Tørning Slot og Len af Brødrene Hans og Hemik v Ahlefeldt for 102,000 Mark lybsk, en meget stor Sum i Datidens Mønt. Hans v. Ahlefeldt, der ejede Slottet og den største Del af Lenet, tilsikrede Kongen af sin Part en arrig Skatteindtægt af 1400 Mark (steder penninge), og for hvert Hundrede Mark Skat udbetalte Kongen ham 4000 Mark samt 10,000 Mark for T'nning Slot med Enemærke, Avl; Møllen foran Slottet,

*) Skinkelborg laa i den sydvestligste Del af Stenderup Sogn og Voldstedet ses endnu noget Vest for den nuværende Lykkesgaard. Fra Samtiden haves ingen Fortegnelse over det Bondegods, der ved Salget 1407 fulgte med Gaarden, men derimod fiere fra senere Tider. Det følger dog af sig selv, at disse ikke ganske stemme overens, da Delinger eller Sammenlægninger kunne have forandret Gaardene. Endnu 1580 opfores Lenet for sig selv i Amtsregisteret, og det bestod dengang af 28 "Tjenere ${ }^{\text {i }}$ i Stenderup, 5 i Bjært, 4 i Ajtrup, 5 i Binderup, 4 i Straarup og 1 i Skartved.

- Archiv für Staats- und Kirchengeschichte. Altona. 1837.

3. B. S. 376 Anm. 
Fiskeriet o. s. v.; - og paa samme Maade modtog Henrik v. Ahlefeldt 36,000 Mark for de 900 Mark Skat, som han havde af Godset.*)

Denne store Handel blev afsluttet i Flensbor'g og som Afdrag i Kjøbesummen modtog Hans v. Allefeldt det holstenske Gods Has eld orf med 5 Marsksogne (for 30,000 Mk.) og Gelting i Angel med alle dertil hørende Byer og Strøgods. Da Kongen modtog Tøuing, tilhørte Haderslev Aint Hertug Frederik, og Kong Hans satte derfor egne Lensmænd paa Tørning, og saaledes opstod Tørninglen i moderne Forstand, der som bekjendt oprindelig omfattede

") Sønderb. Brevregistr. Slesv. Nr.91-100. - Voss" Excerpter. Ahlefeldt (Gregorius-Jørgen) Nr. 84. Ao. 1494:

En wdskoren skreffti screffuit aar efter gudtz burd MCDXCIIII anden, dag sanctomm Simonis et Jude Apostolorum er gjort emellem myn herre oc hr. HIans van Aleuelde om Thörning slott or len ludende, at hr. Hanss van Aleuelde tilsagde myn herre XIIII $\mathrm{d}$ marc steder penninge wisse rentte $i$ thöninglen, som hannem tilkommer, oc at mys herre scall giffue for hvert hundert marke IIII $\mathrm{M}$ marc; item at myn herre skulde giffue her Hanss van Aleuelde $X \stackrel{M}{=}$ marc for thörninge slott met awelen oc möllen for slottet oc enemerck oc fiskerii ete., som samme skrefft ydermer vdwise. -

En wdskorn skrefft vitgiffuit aar effter gudz burdt MCDXCHII anden sanetomm Simonis et Jude Apostolorum dag oc giort emelom my herre Konning oc Hinric van Aleuelde ludendes, at Hinric van Alenelde tilsagde my herre IX c. marc rente steder penninge wisse rente i Thöringlen, som ham tilkom, oe at myn herre scal giffue ham for hvert

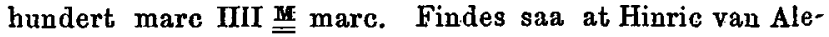
ueldes dell er icke saa stoer i rentte till thöringe, tha scall thet affkorte $i$ hofiuitstolen. Findes der oe mer rentte som Hinric van Aleuelde tilfalder, tha seall myn herre giftue ham for then rentte til eydom som for then anden rentte.

Se: Urkundensaml. IX. Stemann: Geschichte d. off. privat. Rechts. Schleswig. Suhms Historie, 12 og 13 B. Aldste danske Arkivregistranter. I. S. 2. 
Herrederne Gram, Hvidding, Frøs og Kalvslund, medens Norre Rangstrup derimod laa under Haderslevlnus, og. selv efter at Frederik I. havde samlet hele Hertugdømmet paa sin Haand, vedblev Lenet at bestaa ved Siden af Haderslevhus Len, først med sin egen Amtmand og senere i lang Tid med eget Regnskab.

I 100 Aar havde Herrerne paa Tørning hersket over Gram og $i$ to Menneskealdre over de tre andre Herreder. De havde været i Besiddelse af næsten fyrstelig Magt og benyttet deres store Hjælpekilder til at dame et kompakt og afrundet Godskomplex. Ved Salget hørte til Tørning et usædvanlig stort Enemærke (0: Hovmark); thi Ladegaard By bestod dengang kun af. 8 Beskyttelsesfolk (Forbedelsmænd, Husmænd), dẹ betalte hver 8 Sk., og selv om den allerstørste Del af dette Enemærke har ligget til Græsning eller Skov, vilde dog en noget senere Tids Driftsmaade her have fundet rig Anvendelse for Hovbøndernes Arbejde. Selvfølgelig kumne vi ikke længere giøre nogen Adskillelse mellem Gammel- og Ny-Tørning Tjenere, mellem de Bønder, der før Pantsættelserne 1394 og 1421 hørte til Tørining, og dem der erhvervedes ved disse og det senere Kjøb af Gram Herred: Af Pantebrevene ses det, at der i Jels har ligget en befæstet fyrstelig Gaard (Jelshus?), der efter Pantsxttelsen hørte til Tørning, og der kan vel næppe være nogen Tvivl om, at et betydeligt-Antal Bønder i den nærmeste Omegn, særlig i Hoptrup, Vedsted, Hammelev, Skrydstrup, Jegerup, Magstrup og Jels Sogne maa have været Tørning- eller Jelshustjenere selv før Salget 1460, og efter dette faldt jo alle Bønder i Herredet ind under Godset, med mindre de ejedes af andre adelige.

Men som al den gvrige Adel havde Lembekerne og 
Ahlefeldterne desuden forstaret at skaffe sig et meget stort Strøgods omkring i de nærmest liggende Herreder. I Sønderrangstrup Herred ejede de 19 Gaarde foruden Beskyttelsesfolk. I Nørrerangstrup Herred ejede de følgende Gaarde: 5 i Galsted, 3 i Rangstrup, 2 i Rangstrupgaarde, 1 i Hovslund, 2 i Ørderup, 1 i Ovsgaard. I Tyrstrupherred: 1 i Frøruprød, 1 i Ajtrup, 1 i Grønninghoved, 1 i Stobbum, 1 i Rørkjær, 3 i Simmersted. I Haderslevherred: 6 i Ørby, 1 i Overgand, 2 i Bæk, 3 i Vonsbæk, 1 i Sillerup, 2 i Aastrup, 1 i Ultang, 1 i Øsby, 1 i Nølgaard, 1 i Hejsager, 1 i Hajstrnp, 1 i Lilholt, 1 i Hyrup, 1 i Flovt, 7 i Kjelstrup, 1 i Stevelt, 1 i Erlev, 2 i Pamhul, 2 i Nørby-Mastrup, 7 i Sønderby-Mastrup og 5 i Kirkeby. *) Ved Kong Hans's Kjøb kom alle disse Bønder tilbage under Kronen, men hovedsagelig som Frstere.

Ejsbøl (Egilsbøl). Ejsbøls Historie er saare lidet oplyst. Den første Ejer, vi kjende, er en Anders Jonsen, der novnes 1355; senere, 1378, en Johannes Holk, men at han har ejet Ejsbøl, vides km af Omskriften om hans Segl. Derefter kom Gaarden i Familien Rønnov's Besiddelse (1439 Claus Rønnov), og i Slutningen af det 15de Aarhundrede ejedes den af Henneke van der Wisch, Wulfs Søn. Naar og hrorledes han har fanet Gaarden, er ukjendt, men Stemann fortæller om ham, at han $\mathrm{i}$ høj Grad søgte at udvide sine Besiddelser ved Kjøb af Gaarde og Grundstykker rundt omkring i Amtet. Af Here Amtsregistre fremgrar det, at han har solgt Gaard og Gods til Frederik I.**) og da han døde Aar $1500^{* * *}$ ),

\footnotetext{
*) Archiv für Staats- und Kirchengeschichte. 3. B, S. 377.

**) Dith nageschreuen Geuen de lüde van Eggelsbull gekofft van Ilenneke van der Wisch. - Ibid.

***) Stemann: Familien v. d. Wisch. - Jahrb.
} 
maa Salget have fundet Sted før' dette Aar, I hvert Fald var Ejsbøl Gaard og Gods i Hertugens Besiddelse 1520; thi $i$ dette Aar har han underskrevet en Overenskomst med de tidligere Ejsbøltjenere i den forlængst nedlagte $\mathrm{By}$ Stendeved. (Stendet) i Aastrup Sogn om Hoveritjenesten til Haderslevhus. *) Det interessanteste Dokument om Ejsbøl er dog et Bønskrift fra Fæsterne af "Astorp Hovgaard" (Aastrupgaard!), hvori de under 19de Marts 1578 ansøge Hertug Hans i Haderslev om at forskaanes for visse Ydelser. Heri hedder det: „Men siden „Eilsbøl“" er bleven forstyrret og lagt øde, have Eders Fyrstl. Naades Forfædre overdraget Aastrup Hovgaard og det ørrige Gods son Fæste til Eders Undersaatter og sat os saa højt i Skyld med den Besked, at vi ingensinde skulle besværes med anden Pligt eller Tiende."**) Dette er det eneste mig bekjendte Dokument, hvori det ligefrem meddeles, at de lijøbte Adelstjenere behandledes som Fæstere af Regeringen. Forøvrigt opføres Ejsbøltjenerne noget forskjelligt i de Kilder, vi have, men dette hidrører ligesom red Slinkelloorg fra, at der ikke haves Akter fra selve Salget: I et Amtsregister fira 1580 opregnes følgende: I Nørrerangstrup Herred: 1 Fæstegaardmand i Vellerup, 1 i Gestrup, 2 i Gammelskov, 2 i Agerskov, 1 i Refslund, 1 i Hyrup, 1 i Bevtoft, 5 i Gøttrup, 8 i Aabøl, 1 i Aabølling (?), 4 i Tislund og 1 Kirketjener sammesteds. I Haderslev Herred: 4 i Moltrup, 2 i Bramdrup, 5 i Rovstrup, 2 i Errigsted, 8 i Vonsbæk, 7 i Sillerup, 2 i Feldum, 1 i.Kokjær, 2 i

4) Gemein. Archiv XXII. 4. - Delvis trykt i Michelsen: Ueber die vormalige Landesvertretung in Schlesw.-Holst.1831. S.72.

**) Gemein. Archir XXXIX, 29. K. (1054). 
Knud og 11 i Stendeved (Stendet).*) I alt 72 større $0 \mathrm{~g}$ mindre Gaarde (Trap anfører 76 G.).

Baade Ejsbøl og Tørning ere interessante og højst oplysende Exempler paa, hvorledes Adelsgods dannedes $\mathrm{i}$ Slutningen af Middelalderen. Det var ingenlunde urgammelt Paa begge Steder er det opstaaet ved Kjøb enten af Staten eller af private, paa begge Godser bestod det oprindelig af Strogods, der sar lidt efter lidt udvides, samles $0_{0}^{g}$ arronderes. Men medens Herrerne paa Tørning med deres store Magt- og Pengemidler $\mathrm{i}$ et Par eller tre Menneskealdre gjennemfører denne Arrondering med fast Haand, befinder Ejsbøl sig enclnu ved Salget 1500 paa det første, højst ufuldkomne Trin. Ogsaa denne Gaard har været befæstet, thi Tomten ved eller i den udtørrede Ejsbølsø viser endnu tydelige Spor af Volde og Grave, men dens tilliggende Gods af Grundstykker og Gaarde; spredte milevidt ud over de nærmeste Herreder, fortæller tydelig nok, at de ere indlijøbte af de tidligere Ejere, maske endogsaa for største Delen af den sidste, af Henneke v. der Wisch. $\mathrm{Og}$ det bedste Tegn par, at Omdannelsen kun var lidet fremskreden, turde være dette, at Gaardene i Ejsbøl endnu 200 Aar senere havde deres Jorder liggende i Markfællesskab med Haderslev By. Det kan altsaa ikke være lykkedes Herrerne paa Ejsbøl at danne et stort Enemærke eller en Hovmark, den første Betingelse for et godt ordnet Gods og for Anvendelsen af Hovbøndernes Arbejde.**) - Ved

*) Archiv für Staats - und Kirchengeschichte. 3. B. S. 375-76. Anm.

**) Aastrupgaard kaldes dog en Hovgaard, og da den maaske har ligget i Aastrup Sogn, turde heraf sluttes, at Hoveri i moderne Forstand ikke har varet nkjendt paa Ejsbøl i det 15de Aarhundrede. 
enkelte andre store Samlinger af adeligt Bondegods i Haderslev Amt møde vi senere nøjagtig de samme Forhold, men forøvrigt havde de fleste Adelsganrde i Midten af det 16de Aarhundrede deres Enemærlier eller Hovmark fuldt udskilt af Markfællesskabet; naar dette el sket, kan dog ikke nærmere eftervises, og det fortjener ogsaa at bemærkes, at hele Enemærket sjælden eller aldrig dreves fra selve Hovedgaarden, men at en Del af dette var overladt i Frste til Bønder og Boelsmænd. Da Kong Frederilk II. satte sig i Besiddelse af Adelens Gods, faldt disse Bønder som det første Offer for den mere rationelle Godsdrift, han indførte.

I det hele var Tiden umiddelbart efter Reformationen: neget gunstig for Adelens Bestræbelser efter at dame nye Sædegaarde eller afrunde deres ældre Besiddelser. Gejstlighedens Ejendomme, der ligesomi Adelens mest bestod af Strøgods rundt omkring i Landet, kastedes pludselig ud paa Markedet $0 \mathrm{~g}$ fremkaldte talløse Mageskifter $\mathrm{og}$ Salg.

Samtidig indtraf store sociale Omdamnelser. Krigstjenesten gik mere og mere over til lejede Hære, en stor Del gejstlige Embeder, der tidligere havde hørt til Adelssønnernes Forrettigheder, faldt bort, Stats- og Skatteudgifterne forggedes, Fordringerne til Luksus og Velvære steg, den nye Verdens Opdagelse fremkaldte en stærk Nedgang i Pengenes Værdi og en tilsvarende Stigning af Kolnpriserne. Det kunde betale sig at drive Godserne, og Adelen kastede sig derfor fra nu af næsten udeluklkende paa Godsdriften. Men den første Betingelse for en rationel Drift var, at Strøgodset samledes. Derfor mageskiftedes, byttedes, solgtes og kjøbtes der overalt, af Regering som 
af private; Gods og Tjenere gled ustandselig fra Haand til Haand, og enkelte Mænd samlede uhyre Godsmasser. Rantzanerne paa Lindeved ejede $f$. Ex. ikke færre end 347 større og mindre Ejendomme i 37 Sogne, og enkelte adelige truede med at opsluge hele Landskaber (Josias v. Qualen). Man regner, at Adelen var Herre over en Tredjedel af Danmarks Rige, og i Aarene fra 1572 til 1588 for'toges alene i Kongeriget ikke frerre end 330 Mageskifter. Det gjaldt om at sætte alt det nylig erhvervede Bondegods i Forbindelse, at samle alt sammen omkring Hovedgaardene, at danne og afrunde sammenhængende Godskomplexer med store Hovmarker og at omdanne Bøndernes Pligtkjørsler til virkeligt Hoveri, til Spand- og Gangtjeneste. Overalt byggedes. De statelige Herregaarde rundt omkring i Landet rejste sig i denne Periode, for en stor Del ved "Tjenemes" Arbejde, og.i Slottenes Nærhed opførtes store Ladegaarde, ligesom Hovmarken lrom i passelig Orden, for at Fæsterne overalt kunde være ved Haanden til Arbejde. Denne Udvikling, der i høj Grad stotterles af Adelens Hals- og Haandsret, førte i Holsten og Sydslesvig til Livegenskab, og hvis Adelen i Haderslev Ant havde faaet $\mathrm{Tid}$ og Lejlighed til at komme med $\mathrm{i}$ Bevægelsen, vilde dette Uvæsen sikkert ogsaa have bredt sig til Nordslesvig.

Den mest udprægede Repræsentant for denne Bevægelse, .len bedste Type paa en Grundlægger af Gods i stor Stil er Hertug Hans d. yngre paa Sønderborg. Han omdannede sit lille Hertugdømme til en Rakke fortrinlig drevne og meget rentable Godser med en forkuet og forarmet Bondestand, og for den største Del af Datidens Adel stod han som et følgevardigt Mønster. Ogsaa Fong Frederik II. for- 
fulgte, omend paa en lempeligere og langt mere menneskelig Miade, det samme Maal, og med stor Iver kastede han sig ind i meget vidtløftige Mageskifter og Godstransaktioner. Han udkjøbte Adelen i Skanderborg og Koldinghus Amter,;) og da han 1580 kom i Besiddelse af Haderslevlus og Tørninglen efter Farbroderen Hans d. ældre, gav han sig ajeblikkelig i Færd med en lignende Udrensning her. Dette gjorde han ikke alene for at forbedre Amtet — som det almindeligvis siges - og for at skaffe sig en betydelig Vildbane, men ogsaa og navnlig for at damne store kgl. Ladegaarde med vidtstrakte Hovmarker, hvor Amtets Bønder maatte udføre Arbejdet. Kongens Bestræbelser gik øjensynlig i Retning af at omdanne Amtet til et eneste stort Gods med et passende Antal Ladegaarde spredte ud over Sognene; derfor nedlagde han flere Byer, og kun hans tidlige Død 1588 forhindrede ham i at se denne Plan fuldendt. Den rationelle Godsdrift naaede altsa først med ISong Frederik II. til Haderslev Amt, og efter at vi have gjort os bekjendte med Godskjøbene i det enkelte, skulle vi til Slutning sige et Par Ord derom.

Emmikser'nes Gods. Emmikserne var en gammel nordslesvigsk Slægt. Deres Stamfader var Hr. Esbern Tagesen, der nævnes Væbner 1387 og 92, men senere blev Ridder og var død 1412. (Script. Rer. Dan. VIII. 7.) I det 15de og 16de Aarhundrede var Refs $\emptyset$ i Sommersted Sogn deres Hovedgaard, men til forskellige Tider' ejede de desuden Tyrstrupgaard, Brændore og muligvis ogsaa Trabdrup (Taaggerup) samt meget Strøgods rundt

*) Saml. til Jysk Topografi og Historie. 7 B.S. 1 flg. Mange genealogiske Notitser skylder jeg Arkivsecretair Thisets Velvilje. 
omkring i Amtet. De vare besvogrede med de mest ansete Adelsslægter i Omegnen. Af Ejerne paa Refsø lijendes Esbern og Hartvig Emmiksen, Sønnesønner af Hr. Esbern Tagesen, derefter Hartyigs Søn Otto Emmilisen (1488 til 1523), dennes Søn Movrids Emmiksen, der 1537 gjorde Skifte med sin Broder Anders efter deres Broder Hans, og fik Anders da Gods i Høgerup og Stepping, hvorimod Movrids fik al Anders's Part i Refsø, samt den Halvpart, deres Søster Sophie havde arvet efter Hans Emmiksen i samme Gaard, idet de begge i Fællesskab forinden havde aflijøbt hende denne Part. Movrids's Søn og Efterfølger Otto Emmiksen- afhændede 1572 sine Fædres Gaard og Gods til Kong Frederik II. for 20,000 Mark lybsk, men da Hertug Hans den ældre dengang ejede Amtet; overdrog Kongen Gaarden og Bønderne til ham. I Salgsdokumentet*) hecller det, at „Otte Emmickszenn till Refsøe" tilskøøder Kongen sit „i Synder-Juttlandt Liggendis arffuegolts“, som er hans Hovedgaard Refsø med Mølle, Holbek, en Gaard, der aarlig giver i Landgilde 1 Ørtug Rug, 2 Ørt. Byg, 2 Ørt. Havre, 1/2 Td. Smør og 1 Svin, naar Olden er; to mindre Gaarde i Iegevraa samt to Huse i Skoven. "Og ele forme Gaarde og Huse byggede paa Refsøgands Enemærke." Men desuden solgte Otto E. efternævnte Bøndergods: I Kastriaa 4 Gaarde, i Sommersted 2 Gaarde og 4 Landbol, der "have Tov ï Marken, men ingen Lod i Skoven", i Lert 1 Landbol, i Simmersted 1 Gaard og i Stepping By 1 Gaard. Men Emmilsserne ejede endnu langt mere Gods i Amtet; thi da rede Penge paa den Tid vare sjældne, havde Adelen for Skik at dele Bøndergodset

W) Pergamentskøde paa Dansk. Gem. Ark. Casp. 22. 
mellem Børnene, og dens yngre Sømer og Døtre toge da ofte Bolig paa en Bondegaard og levede af demes Drift og af Landgilden fra de øvrige. Ved Giftermaal kom det adlelige Strøgods derved paa meget forskjellige Hænder. Saaledes ejede Margrethe Emmiksen, ${ }^{*}$ ) en Datter af Movrids Emmiksen paa Refsø, 3 Gaarde (hvoraf hun selv paaboede den ene) og 4 Landbol i Kastvraa, 2 Gaarde i Simmersted, 1 Gaard og 2 Landbol i Lert, 1 Gaard og 2 Huse i Ajtrup samt 1 Gaard i Stepping, i alt 8 Gaarde $\operatorname{og} 6$ Landbol. Ved en Mageskifteakt, der ordnedes i Skanderborg den 27 de Decbr. 1582, overdrog hum Kong Frederik II. disse Ejendomme og modtog som Vederlag to Gaarde i Vends Herred af Sct. Knuds Klostergods samt en, Sum Penge. Og noget tidligere havde hendes Søster Thale Emmiksdatter, ${ }^{*}$ ) der var gift med den berygtede Biler Brockenhus til Søndergard, ligeledes solgt „sit Arvegods i Sønderjylland" til Kongen, nemlig 1 Gaard i Lert, 1 Gan'd og 1 Landbol i Stepping og 2 Bol i Kastvraa. ${ }^{* *}$ ) Men desuden ejede "Jomfruerne Magdalena og Margrethe Emmiksdatter"*) til Mildinge i Fyen en Del sønderjysk Arvegods efter deres Fader Anders Em miksen til Stensgaard i Fyen, der, som alt nævnt, var en Broder til Movrids Emmiksen paa Refsø. Dette Gods, der ved Kjøbebrev af 30te Maj 1583 overdroges til Kongen, omfattede 1. Gaard i Hejsager med Molle og Aalegard (Hejsagergaard), 1 Gaard i Tange i Halk Sogn, 3 Gaarde og 1 Kaad i Højrup samt Jomfruernes formentlige Rettig-

*) Skøder i Top. Saml. paa Pergament.

**) Den 3. Oktbr. 1581 havde Eiler Brockenhus solgt 1 Gaard i Kastvraa „i Sønderjylland“ til Kongen. Skøde i Top. Saml. paa Pergament. 
heder til Saatrupgaard, 1 Gaard i Stepping, 1 i Kolstrup, 3 i Sommersted, 1 i Simmersted samt 1 Gaard og 2 Huse i Lert, eller i alt 12 Gaarde, 1 Mølle og Aalegaard og 3 Huse. Kjøbesummen angives ikke. - Formodentlig har den største Del af dette Bondegods oprindelig ligget under Refsø.

Tovskov var en af Nordslesvigs æeldste Borge. Den laa i den vestligste Udkant af Sommersted Sogn mellem Mølby og Lert, i en nordvestlig Fortsættelse af Tovskov Mølledam, hvor Tomten endnu tydelig ses. I et Lovebrev fra 1374 loves Kong Valdemar Atterdag, "at det Slot, som kaldes "Thoweskowe", skal være Rigens aabne Slot i Nød og Lyst og neder skal brydes og ødelægges, naar Kongen af Danmark tilsiger. “*) I Slutningen af det 14de og $\mathrm{i}$ den første Halvdel af det 15de Aarhundrede tilhørte Borgen Familien Eberstein, nemlig 1391 Hr. Albert Andersen, der tillige ejede Rydhave i Jylland og var gift med Elisabeth Henningsdatter Podebusk, som var Enke 1413, og deres Søn Anders Albertsen 1408. Fra denne Sidste kom den ved Giftermaal til Ridder Jon Jonsen Lille, der var af Slægten Skram og gift med Anders Albertsens Søster. Han levele endnu 1426, og hans Søn Anders Jonsen skrives 1451 til Tovskov (Geh. Ark. Aarsber. II. T. 25, 69), men synes senere at have solgt Tovskov, thi $14 \% 6$ skriver han sig ikke længere til denne Gaard, men boede i Arnum. Derefter gik Gaarden og Godset over til Reventlowerne paa Gram. Den sidste af disse, Johan R. til Gram og Tovskov, gift med Birgitte Lindenov fra Drenderup og Fobeslet, efterlod sig kun to Døtre, nemlig Anna, der arvede

*) De ældste danske Arkivregister. I. 
Gram, og Magdalene, gift med Henrik Rantzau Ottesen (til Bülck), der fik Tovskov. Henrik Rantzau til Tovskov deltog i Grevefejden par Chr. III.s Side, var dernæst fra 1542-44 Amtmand over' Haderslevhus- og Tørninglen, traadte efter Hertugdømmernes Deling 1544 i Hertug Hans den ældres Tjeneste og maa være død omkring Aar 1563. ${ }^{*}$ ) Hans Søn Melchior Rantzau mageskiftede Slottet og Godset i Juli 1583 mod Solvig. i Tønder Amt, som Kong Frederik II. nogle faa Uger i Forvejen havde erhvervet af Erik Lange til Engelholm i Jylland. Af Frederik II.s Skrivekalender ses det, at han har opholdt sig paa Tovskov, men om Slottets eller Hovedbygningens senere Skæbne vides aldeles intet, og, saavidt mig bekjendt, ere Ruinerne aldrig blevne undersøgte. Til Gaarden synes ikke at have hørt noget Enemærke, men ved Mageskiftet lagde Kongen ikke færre end 77 Gaarde, 1 Molle og 61 Landbol og Huse ind under Amtet. Dette Gods var fordelt paa folgende Maade: I Grønnebæk 5 Gaardm., 7 Landb., Damsgaard, i Ørsted 10 Gaardm, 10 Beskyttelsesfolk (Husmænd), i Lert 8 Gaardm., 5 Landb., i Mølby 3 Gaardm., 6 Landb, i Oxenvad 3 Gaardm., 4 Landb., i Magstrup 2 Gaardm., 2 Landb., i Bæk 1 Gaardm., 1 Beskyttelsesmand, i Modbøl 3 Gaardm., 1 Beskyttelsesm., i Terp 2 Gaardm., i Stenderup 4 Gaardm., 1 Beskyttelsesm., i Dover 8 Gaardm., 6 Landb., i Skodborg By 3 Gardm., 4 Landb., i Skustrup 2 Gaardm., 1 Beskyttelsesm., i Barstrup 1 Gaardm., i Thyrholm 1 Gaardm., i Søndernæs i Hviddingherred 1 Gaardm., i Vestervedsted 1 Gaardm., i Vinumgaarde 2 Gaardm., i Ottersbøl 1 Gaardm., i Lorup (Laurup) 1 Gaardm., i Arnum

*) Rigsarkivets Diplom. Danske Magaz. 3 R. 4 B. Om Pro cessen med Detlev Ahlefeldt se: Voss' Excerpt. Jahrrb. X. etc. 
7 Gaardm., 13 Landb., i Stensbæk 1 Gaardm. (der giver 10 Mark for F'rihed), i Gjelstoft 3 Gaardm., Torskov Molle. Alle disse Tovskovtjenere vare hoveripligtige eller maatte betale en vis aarlig Sum for "Frihed", der for 7 navngivne Gaardmæend i Arnum aarlig beløb sig til 3 Mark hver; de maa sikkerlig ogsaa opfattes som Frstere, om end Melchior Rantzau i Mageshiftsdolrumentet synes at skrjelne imellem Bønder og Fæstere (Pauern oder Landtsten). I en Jordebog fra 1595 opføres Tovskovtjenerne med folgende samlede Sliattesum: Penge: 269 Mark 4 Sk. Rug og Mel: 3 Læst 22 Ørtug. Byg og Malt: 1 Læst 1 Ørt. Havre: 16 Ørt. Beder og Faar: 37. Lam: 10. Magre Gæs: 60. Høns: 110. Æॄg: 160. Smør: $4^{3} / 4$ Td. Fødenød at fodre: 63 . Svin: $63{ }^{*}$ )

Fovslet eller Fobislet i Øddis Sogn nævnes. allerede $1390 \mathrm{og}$ var da tilligemed det nærliggende Drenderup i Familien Lindenovs Besiddelse. Ved Skøde af 4. Jan. 1583 overdrog Ejeren Hans J o hansen Lindenov Gaard og Gods til Kong Frederik II. Salgsprisen nærnes iklie. Til Gaarden hørte følgende Gaarde og Huse. I Fovslet By: 10 Gaarde og 9 Bol, 1 Gaard i Feld og "Feldtmølle", 2 Gaarde og 3 Landb. i Øddis, 1 G. i Vonsild, 1 G. i Dalby, 3 G. i Skartved, 2 G. og 2 Landb. i Bjært, 2 G. i Binderup, 1 G. i Grønninghoved, 1 G. i Hejls, 2 G. i Kobbersted, 1 G. i Aastorp, 1 G. i Tapsore, 1 G. i Jegerup, 1 G. i Nustrup, 3 G. i Lyndt, 1 G. i Halk, 1 G. i Stenderup, 1 G. i Vilstrup, 1 G. i Kjærstrup, samt 1 Landb.

*) Tysk Mageskifteakt. dat. Haderslev 24. Juli 1583. Til Vejledning hidsættes følgende: $1 \emptyset \mathrm{rtug}$ Rug ell. $\mathrm{Mel}=10 \mathrm{Skpr}$. 1. grt. Byg ell. Malt $=12 \mathrm{Skpr} .1$ Ørt. Havre $=20$ Skpr. 1 Læst er altid 24 Ørtug. 
i Vedsted og 1 i Magstrup. Taarning Mølle (?). Altsaa hom ved denne Handel $3^{*}$ Gaarde, 1 Mølle og 18 Landbol ind under Amtet. Endvidere ses, at Fovsletby endnu 1.583 var ved Magt, men derimod er den forsvunden 1595, eg Kong Frederik II. maa derfor, sandsynligvis kort efter Jajobet; have ladet den nedlægge og afbryde. Dens Stenbro og Toftegrøfter ses endnu Øst for Fovsletgaard.*)

Vilstrup Gaard er paa en Gang et fortrinligt Exempel paa adelige Nydamnelser i Reformationstiden og paa, hvorledes holstensk Adel forstod at arbejde sig ind i nordslesvigske Egne. Den sidste katholske Biskop i Slesvig, Gottschalk v. Ahlefeldt, der meget egenraadig aflrandede Stiftets Bøndergods baade ved Salg og Gave, havde overdraget Goske Rantzau (Feltherren Daniel Rantzan's Fades') til Nienhof i Westensee Sogn i Holsten noget biskoppeligt Strøgods i Haderslev Amt, særlig paa Haderslev Næs, og paa dette Grundlag søgte Goske Rantzan og hans Søn Tøunies Rantzau efter ham at danne en. aclelig Sædegaard i Vilstrup og at samle Bondergods til. denne. I sidste Henseende var han ubetinget heldig. Han var meget gridsk efter Jord, kom allerede før 1528 i Besiddelse af Vandrup Gaard i Nørrejylland, arvede 1533 Nienhof, og efter Grevefejlen satte han sig ogsaa i Besiddelse af Ulfeldternes forbrudte Gods Bengand i Bjært sogn og Vargaard i Stenderup Sogn **), indtil endelig Hertug Hans 1556 atter delvis fravristede ham disse Besiddelser. Desuden raadede han over store Pengemidler, og Kongen

*) Top. Saml, paa Pergament.

*s) Se: Annal. Nord. Oldkyndigh. 1853, S. 62 flg. Angivelsen i Dansle Mag, 4 R. 3 B., S. 261 om Hejls Vargaard er nrigtig. 
skyldte ham meget store Summer, en kort Tid omkring 1534 synes han endogsaa at have været.Amtmand i Haderslev, og det kan derfor ilkke forundre os, at det lykkedes ham og hans Søn indtil 1583 at bringe 77 Gaarde og 34 Landbol og Huse i Amtet $i$ deres Besiddelse. Hertug Hans den æoldre yndede ikke disse Bestræbelser, og vedvarende negtede han Ejerne Tilladelse til at løse Vilstrupgaard ud af Byfællesskabet. Den havde derfor intet Enemærke eller Hovmark.")

I Aaret 1583 kjøbte Kong Frederik II. Vilstrupgaard og Gods af Tønnies Rantzau for 84,000 gamle Daler. I Shødet, ${ }^{* *}$ ) der er udfærdiget par Tysk og undertegnet d. 11. Septbr. 1583, undtager Rantzau fra Handelen to Gaarde i Haderslev By og de "Boder", der ligge i Gammel Haderslev. Forøvrigt bestod Godset af følgende Gaarde og Huse: Vilstrupgaard, hvorpaa der boer 2 Gaardmænd og 6 Kaadnere, 1 Gaard i Nørby Vilstrup, 3 G. i Lunding, 2 G. i Halk, 4 G. og 1 Beskyttelsesm. i Hejsager, 3 G. og 3 Beskyttelsesm. i Stevelt, 3 G. og 2 Beskyttelsesm. i Hajstrup, 1 G. i Raade, 2 G. i Flovt, 1 i Nørby Mastrup, 2 Beskyttelsesmænd i Sønderby Mastrup, 2 G. i Kirkeby, 4 G. og 3 Huse i Gammel Haderslev, 1 G. $1 \mathrm{H}$. i Moltrup, 2 G. og 1 Hus i Bramdrup, 7 G. i Errigsted, 1. G. og 1 Hus i Aastrup, 1 G. i Vildfang. I Gramherred, i Hoptrup 5 Gaarde og 5 Beskyttelsesm., i Djernæs $1 \mathrm{G}$. og 2 Beskyttelsesm., i Vejbøl' 3 G. og 2 Huse, i Jegerup 1 G., i Ringtved 1 G., i Magstrup 3 G., 1 Landb. og 1 Beskyttelsesm., i Simmersted 3 G. og 1 Beskyttelsesm. I Hejls 1 G., i Anslet 1 G., i Aller 1 G., i Braabæk 2 G.

\footnotetext{
*) Hansb. Registr. X.

*) Top. Saml. paa Pergament.
} 
og 1 Beskyttelsesm., i Refshave 2 G., i Knud 1 G., i Bøgeskov 1 G., i Kabdrup 1 G. og 1 Hus, i Bjærndrup 2 G., i Hjerndrup 2 G. I Hviddingherred, i Emdrup 1 G., i Raahede 1 G., i Havervad Aabølling 1 G., i Rejsby 1 G., i Revslund 1 G. og i Østergasse 1 Gaard. Desuden hørte nogle Gaarde i Slogs og Sønderrangstrup Herred til Godset.

Brændore Gaard i Frørup Sogn. I Frørup boede 1402 en Adelsmand ved Navn Jesse Jversen, der førte Emmiksen-Slægtens Vaaben; men desuagtet skal Brændore først ved Barbara Rigstrups Giftermaal med Hartvig Emmiksen fra Refsø være kommen til denme sidste Slægt. Hans Sønner Niels Hartvigsen (1499) og Emmike Hartvigsen ejede Brændore; den Sidste var gift med Tale Flemining, der bragte ham Gjelskov i Fyen og Møllerup i Jylland. Af deres Dotre ægtede Magdalene Albert Maltesen (Viffert), der med hende fik Møllerup, og Anne Erik Kaas; der blev Ejer af Gjelskov og ogsaa skrives til Brændore. Deres Sønner Ghristian Maltesen (Viffert) til Hageløse og Mogens Kaas ejede hver sin Halvdel af Brændore Gaard og Gods; men den 11te Jan. 1583 solgte Christ. Maltesen sin Part til Kongen "samt efterskrevne Fæstere og Bønder" (Landtsten vnd Bauren): I Frørup 3 G. og 2 Kaad, i Brændore 1 G., $\dot{\mathrm{i}}$ Stepping 1 G. og 2 Kaad, i Højrup 2 G., i Kjærstrup (Jegerup Sogn) 1 G., i Bæk 1 G., i Skustrup 1 G. Og 2 Aar senere, d. 12. Marts 1585, solgte Mogens Kaas' Enke, Anna Rantzau, ligeledes sin Andel til Kongen samt "Godsets Tjenere", der vare: 1 Gaardm. i Stepping,, 1 i Dalslund, 2 i Gejlshus; 3 Gaardm. og 3 Kaadnere i Nustrup Bæk, 1 i Brændore, 1 i Kolsnap, 2 Gaardm. og 1 Kaadner i Sommersted, 1 G. i Magstrup, 1 i Kastvraa 
og 1 i Nustrup. I alt lrom saaledes 24 Gaarde og 7 Landbol tilbage under Amtet.*)

I Aaret 1583 erhvervede Frederik II. endnu en hel Del adeligt Strøgods omḳing i Amtet. Fra $\mathrm{Møg}$ elt $ø$ ader fik han 2 Gaarde i Rangstrup og 2 i Bovlund. - $A f$ Karen $\left.\mathrm{Hak},{ }^{* * *}\right)$ Arendt von Pegou's Efterleverske, tilbyttede han sig 1 Gaard i Frørup, 1 Boel i Hjerndrup og 1 Gaard i Sommersted. Til Gjengjæld fil hiu af Kongen en Gaard i Emdrup i Hvidding Sogn samt Kronens Herijghed $i$ den jordegne Bondegaird i Raahede, som hun og hendes Husbond hayde tilkjøbt sig Bonderettighederne $i$. (Kronens Herlighed bestod i $5 \mathrm{Mk}$. lybsk og $1 \mathrm{Mk}$. for 1 Svin.)

Af Johan Norby til Tagemosegaard paa Fyen og Hustru Marg r e th $\Theta B$ asse, hvis Moder var Anne Emmilssdatter, en Sønmedatter af Otto Emmiksen til Refs $\varnothing$, lijøbte han 5 Gaarde og 1 Bol iHejsager samt 1 Gaard i Lunding. ${ }^{* * *}$ ) Ogsaa en af J. Norby's Gaarte kaldes Hejsagergaard.

Af Benedikt Petersen af Slægten von Deden fra Unevad i Angel $\dagger$ ) kjøbte han for 1000 „ensikilde gamble Dalere K ar nh a ffu eg a ar d" i Hjerndrup med 2 Enemærker og Kobler, 1 Bol og 4 Gadehruse samt 1 Gaard i Stobbum. Benedikt Petersen havde hidtil boet paa Karnhavegaard. I Hjerndrup boede 1334 en Adelsmand Iver Nielsen.

*) Chr. Maltesene Skøde paa Tysk; Auna Rantzau's paa Danst. - Top. Saml. paa Pergament.

**) Mageskifteakten dat. Haderslev d. 8. Juli 1583. Arendi

- v. Pegous havde været Amtmand i Løgumlkloster. - Mageslzifter.

wh*) Skøde i Top. Saml. paa Perg. Undertegnet 7. Juli 1583.

†) Skøde i Top. Saml, paa Perg. Dateret Haderslev den 3. Juli 1583. 
Af Fru Karen Gyldenstjerne Ottesdatter*) til Dybæk, Jørgen Marsvins Efterleverske, hvis Mormoder var Margrethe Sture, kjøbte han Enstedgarrden Vraa i Beftoft Sogn. Den skylder 24 Mk. dansk.

Af Johan Bockholdt til Klingstrup og Hustru Lisebeth Urne tilbyttede han sig 1 Gaard i Anslet By (i „Sönderjudland") mod, at Egteparret til Gjengjæld fik Jus patromatus til Skaarup i Lunds Herred, Fyen.***)

Af Morits Podebusk til Kjørup, gift med Magdalena, en Datter af Claus Sehested til Spandetgaard (saaledes kaldes endnu den nordlige Del af Spandet By), kjøbte Kongen 7 Gaarde og 2 Beslkyttelsesmænd i Branderup, 3 G. i Rurup, 1 G. i Musvang, 3 G. i Stenderup, 1 G. i Allertp, 9 G. i Toftlund, 2 G. i Kjergaard og 2 G. og 2 Iraad i Roager. - Overdragelsesdokumentet er ikke liengere tilstede, og der kan derfor intet nærmere oplyses om Handelen, men denne er afsluttet i Aaret 1583.

Ved disse Transaktioner lagde Kongen 44 Gaarde og 11 Landbol og Huse ind under Amtet.

I Aarene 1584-85 fortsatte Kongen med samme Iver sine Bestræbelser for at rense Amtet for adeligt Bondegods og Adei. Den 6te Marts 1584 undertegnedes det store Mageskifte med Hans den yngre; der ved Arvedelingen efter Hertug Hans i Haderslev havde faet en stor Del Gaarde i Amtet. Ved denne Lejlighed kom 22 Gaardo i Bolderslev, nogle Gaarde i Todsbol, Enlev og Gjenner samt Julernes Gods under Stolvig i Løjt Sogn ind under Amtet, ligesom 6 Gaarde og 3 Husmænd i Overjersstald, 4 G. i Abkjær og 4 G. i Nederjersstald samt den største

*) Skøde i Top. Saml. paa Perg. Dat. Haderslev d. 6. Juli 1.583.

**) Dat. Krbhvn. 30. April 1583. 
Del af Hyrup og Bevtoft Byer med Branderup og Beftoft Mølle atter lagdes tilbage under Amtet, hvorfra de for et Par Aar siden vare blevne udskilte. Der er dog næppe nogen Grund til at regne disse Gaarde med til Adelsgodset, og de ville ikke blive tagne med $\mathrm{i}$ det endelige Opgjør.

Kjeldet (Kehlet) eller Kjeldved i Fjelstrup Sogn i Haderslev Herred ejedes i Midten af det 16de Aarhundrede af Gunde Lange til Breininge og Karen Breide (en Datter af Hans Breide og Thale Emmiksdatter paa Hejls Vargaard). Gunde Lange, der tilhørte Familien Lange-Munk med de tre Roser, har - saa formoder jeg - faaet Gaarden med sin Hustru. I Følge Trap skulle deres Portræeter endnu opbevares paa Gaarden. Fra dem gilk Kjeldet ved Giftermaal over til Hans Rostrup til Skovgaard, der i Januar 1.584 mageskiftede sin Hustrus Arvegods i Sønderjylland mod Gods i Skørring Sogn i Framløv Herred. Kong Frederik modtog „först vdi Harslöffherred i Fjeldstrup Sogn Killwid ", ${ }^{*}$ ) hans Hovedgaard med Bygning og Enemærke; samt efterfølgende Ejendomme med Landgilde, Herlighed og Rente: 1 Gaard i Sillerup, 3 G. i Vonsbæk, 2 G. i Fjelstrup, 1 G. i Favervraa.

Diderik Höiks Gods. Familien Höik's eller Høl's Sæelegaard var Avnbølgaard i Sundeved, men en Mand af Slægten Didrik Movridsen Höik, der var gift med Mette Bṛeide af Vargaard, ejede en Del Strøgods i Haderslev Amt.

I Februar 1584 kjøbte Kongen dette Gods, der bestod af 1 Gaard i Bøgeskov, 1 G. og 2 Kaad i Hadersler-

*) Top. Saml. paa Perg. - Artikel af Begtrnp i Biogr. Tidsskrift. 1840 . 
Bramdrup, 1 G. i Hjerndrup, 2 G. i Favstrup, 1 G. i Hvinderup, 3 G. i Aller, 1 G. i Stobbum, 1 G. i Mæng, 1 G. i Anslet, 2 G. og 1 Kaad i Stevelt, 1 G. i Sverdrup, 3 G. og 1 Kaad i Tamdrup, 1 G. i Raade, 1 G. i Hyrup, 2 G. i Halk, 1 G. i Hejsager, 3 G. og 3 Kaad i Kjelstrup, 1 G. i Vilstrup, 1 G. i Nørby, 3 G. og 5 .Huse i Kjærstrup, 3 G. i Vandling. Desuden fik Kongen ved kạmme Handel nogle Gaarde i Saattrup, Ulderup og Snogbæk i. Sundeved samt 5 G. i Bøgslund i Kjærheried.

Til Haderslev Amt kom i det hele 34 Gaarde og 12 Kaad eller Huse.*)

Drenderup Gaard i Øddis Sogn. Den 20de Decbr. 1584 undertegnede Hans Christoffersen Lindenov, Befalingsmand paa Bergenhus, et Mageskiftebrev med Kong Frederilk II. paa Antvorskov, hvorved han afstod „Drenderup vdi Synd. Judland liggendis mett mere guodtz vdi Norre- och Synder Judtland“, og fik igjen Ørslevkloster med noget af dets tilliggende Gods. I Mageskiftet var indbefattet: Drenderup Hovedgaard med Bygning, Avl og al dens videre Tilliggende og Enemark; Drenderup Mølle med en aarlig Skyld af 12 Ørtug Mel; Thinderbeckgaard, der aarlig skatter $1 \mathrm{Td}$. Smør, 1 Brandsvin, 1 Fødenød, 1 Lam, 1 Gaas og 2 Høns; Ġarden Hønsgalhoje med samme Skat, Relklandseg og Langvad, 2 Bol, der hver skylder 2 Daler, 1 Otting Smør. Disse Gaarde synes at have ligget paa Drenderup Gaards Enemrerke, og med Undtagelse af Riglandseg ere de forsvundne allerede straks efter Overdragelsen til Kongen, der formodentlig har nedlagt dem for at forstørre Hovmarlien, eller ogsaa har han

*) Tysk Skøde. Top. Saml, par Perg. 
lagt Jorderne ind under de saakaldte $\emptyset$ ddisgaarde $(5 \mathrm{G}$.), der i Jordebogen fra 1595 anføres som kjøbte af Hans Chr. Lindenov paa Drenderup, uden at Mageskiftdokumentet. omtaler dem. Til Dienderup hørte endvidere 12 Gaarle og 1 Boel $i$ Øddis By og paa en af disse Gaarde (de: aarlig gav 1 Td. Smør, 1 Brandsvin, 1- Ørtug Havre, 1 Føden ød, 1 Lam, 1 Gaas, 2 Høns og 3 Mk. lybsk i Gjæsteri) boede Faderen, Christ offer Johansen Linden ov. 2 G. i Bramdrup, 1 G. i Sølund, 1 G. i Frørup, 1 G. i Favrviaa, 2 G. i Mæng, 1 G. i Langvad og 1 G. i Lorup (Arrild Sogn). - Ved Mageskiftet kom altsaa 1 Hovedgaard, 1 Mølle, 25 Gaarde og 1 Boel til Amtet.*)

Tyedsgard i Dalby Sogn tilhørte i Slutningen af Middelalderen den gamle nordslesvigske Adelssiægt T eg enhus (Theding- Thin-Tinhus). Markvard Tegenhus ejede Gaarden 1480 og 1492 , og han navmes endnu mange Aar senere; han var alt 1473 Forstander i For Fruekloster i Roskilde, skrives 1486 til Tvedsgaard, og var 1493 Lehnsmand paa Hagested. 1543 ejede hans Son Otto Tegenhus (der 1523 ligeledes var Lehnsmand paa Hagested) Godset, men senere gik dette over til Jost Andersen Ulfeld, der var en Søn af Anders Ebbesen Ulfeld til Oregaard i Fyen og Else Tegenhus, en Datter af Markvard Tegenhus paa Tvedsgaard. 1551 havde Jost Andersen Gaarden og endnu 1.577 skrives hans Enke til samme. Deres Datter Anne Ulfeld blev gift med Jorgen Friis til Vaskjergaard og ved Mageskifte af 3. August 1585 overdrog

*) Mageskifter 559-560. En Del af dette Gods havde tidligere paa Aaret 1584 ogsaa været paa Kongens Haand, idet han havde tilbyttet sig det af Christoffer Lindenov, men atter mageskiftet det bort til Hans Lindenov. 
han Gaard og Gods til Kong Frederik II. Af sit og sin Hustrus "Arvegods i Sønderjylland " udllægger han til Kongen "Tvedisgaard", der er beboet af to Bønder og en Landboelsmand, 6 Gaarde, $1 \mathrm{Bol}$ og 10 Gadeluse i Tvedsby, 1 Gaard i Binderup, 1 G. i Ajtrup, 1 Gaard "Smøgelund“ i Tyrstrup Sogn, samt i Seest (i Tyrstrup Herred) 1 G., 1 Boel og 1 Gadehus, og endelig Halvparten af Tredsmølle (Dalbymølle!), der giver 22 Ørtug Mel. *)

Stenderup Vargaard og Bengaard i Bjert Sogn tillhørte i Slutningen af det 15de Aarhundrede Hartvig Sinalsted (eller Smalsti) og senere dennes Søn Timme Smalsted, men da denne døde uden Arvinger, gik Gaardene over til hans Søster Hilleborg Smals teds Børn. Hun var bleven gift med den ovennævinte Anders Ebbesen Ulfeld til Oregaard og havde med ham Sønnerne Hartvig og Otto Anderssønner Ulfeld; hun døde imidlertid allerede 1498 og Manden giftede sig anden Gang med Else Tegenhus af Tvedsgaard, der blev Moder til Jost Andersøn Ulfeld. - Hartvig faldt i Grevefejden og Otto, der var en Tilhænger af Christian II., forbrød sit Gods i samme Krig og døde i Udlandet 1543. Forinden sin Afrejse havde han imidlertid pantsat sit slesvigske Gods til Johan Burchschreiber i Haderslev, og Goske Rantzau til Vilstrup oplkjøbte dette Pantebrev og satte sig i Besiddelse af Vargaard og Bengarrd indtil 1556. Hertug. Hans i Haderslev var imidlertid bleven opmærksom paa, at han som Landsherre kunde gjøre Krav paa Otto Andersøns forfaldne Gods, og 1556 tvang han Rantzau til at afstaa det halve Bengaard (2 Bønder i Bengaard og 1

4) Mageslzifter i Rigsarkivet. - Annal. Nord. Oldkyndighed. 1853. S. 62, flg. 
i Ajtrup *), der lagdes ind under Amtet. Samtidig angreb Jost Andersøn tlfeld Goske Rantzaus Ret til Vargaard og paa en eller anden Maade maa det være lykkedes ham at komme i Besiddelsen af denne, da han 1558 nævnes til Vargaard og hans Enke ligelecles 15\%7. **) Fra hende gik Gaard og Gods over til to af hendes Døtre, Edel, der var gift med Kjeld Brockenhus til Lerbæk, og Ellen, der var gift med Mads Eriksen Vadspyd til Søgaard, og disse afstod ver Mageskifte - henholdsvis den 25de og 30te Juli 1585 - deres Hustruers „Arvegods i Sønderjylland" til Kongen. Kjeld Brockenhus overdrog til ham 2 Gaarde i Varmarkby, samt Halvparten af en Gaard, Halvparten af en Eng kaldet Gaasemade, Halvparten af en større øde Jord Rødkobbel, Halvdelen af en wde Bygge kaldet Laurits's Tofte, item $4 \mathrm{Bol}$ sammesteds, „som min kjære Svoger, ærlig og velbyrdig Mand Mads Eriksen til Søegaard og jeg have havt tilsammen". Ligeledes Halvparten af en Enemærke Skov til Varmarklby og desuden 1 G. i Ajtrup, 3 G. i Skartved, 1 G: i Bjært og Taarning Mølle, der aarlig skylder 26 Ørtug Mel. Mads Eriks en overdrog til Kongen: Hovedgaarden Vargaard, sin Del af de ovennæunte Bol og Jorder i Varmark By, desuden vistnok 2 Gaarde i samme By, 1 Gaard $0 g$ 4 Landbol i Ajtrup, 1 G. i Bjært, 2 G. og 2 Bol i Skartved, 1 G. i Binderup, 1 G. i Dalby, 1 Bol i Favstrup og sin Andel af Treds (eller Dalby) Mølle, der giver 22 Ørtug Mel. I Jordbogen fra 1595 henregnes 24 Gaarde, 2 Møller og 11 Boel til Vargaards Gods. ${ }^{* * *}$ )

\footnotetext{
3) Archiv für Staats- u. Kirchengeschichte. 3. B. S. 376.

m**) Annal. Nord. Oldkyndighed. 1853. S. $62 \mathrm{flg}$.

***) Mageskifter. 571-80. I Jordebogen henregnes 9 Ejendomme af Varmarkby til Kjeld Brockenhus's Andel.
} 
I Aaret 1584 tilkjøbte Kongen sig endvidere af Christen Munk (vistnok Christen Munk til Ørehoved, gift med Dorte Rosenkrantz Bendixdatter fra Kogsbøl): 1 Gaard i Kolstrup, 1 G. i Magstrup og 1 G. i Ørsted.

Af Peter Iverson (Baden) ${ }^{*}$ ) til Fritsø i Norge og Hustru Fru Margrethe Breide kjøbte han d. 17. Oktbr. 15841 Gaard i Hjerndrup, 2 Gaarde i Nustrup-Bæk og 1 G. og 1 Landbol i Gammelgab paa Broagerland.

Af Jomfru Margrethe Skougaard til Sanderumgaard i Fyen tilbyttede han sig ved Mageskifte af 6. Jan. 15851 Gaard i Kastvraa og 1 G. i Simmersted. Til Vederlag fik hun Livsbrev paa nogle Kronens Gaarde i Davinde i Fyen. ${ }^{* *}$ )

Af Erik Lange til Engelholm tilkjøbte han sig under 20de April 1585 og 9de Juni 15863 Gaarde i Aaved (Ovitt) i Vodder Sogn, 2 Gaarde i Rost og $1 \mathrm{G}$. i Lorup i Arrild Sogn, 1 G. i Stensbælk og 1 G. i Arnum. ${ }^{* * *}$ )

Ved Mageskiftebrer med Jørgen Rosenkrans til Rosenholm tilbyttede han sig 1586 en større Gaard $i$ Studsbøl i Oxevad Sogn, 2 Gaarde og 2 Bol i Østerlinnet og 1 G. og $2 \mathrm{Bol}$ i Hjerting. Rosenkrans fik Gods igjen i Østerlisbjærg Herred i Jylland. $\dagger$ )

Af Ludvig Munk til Nørlund kjøbte han en Gaard i Stepping. + )

Af Gabriel Schinkel (hans Farmoder en Tinhus)

") Skødet dat. Helsingør d. 17. Oktbr. 1584. Jysk Reg.

n*) Mageskiftet dat. Sanderumgaard. Hellig 3 Kongers Dag 1585. Orig. paa Perg.

***) Orig. paa Perg. Top. Saml.

†) Jysk Reg. 13. Septbr. 1586.

††) Gave- og Skødebrev dat. Helsingør 23. Febr. 1586. 
îl Søholm kjøbte Kongen for 4000 Rdll. d. 3. Decbr. 1586 følgende Gaarde i Frøs Herred: 1 G. i Holm, 5 G. og 3 Kaad i Hygum, 1 G. i Fedsted og 1 G. i Rødding. *) Altsaa lagdes ved disse Smiaahandeler 30 Gaarcle $0 g$ 7 Bol ind under Amtet.

Vandlinggard eller Gramgard ved Vandling yaa Haderslev Næs ejedes 1548 af Hans Reichenbach (Traps Statistik) og fra 1.556 af Jørgen Møet (George Møet), der clen 12. Decbr. $158 \%$ solgte den tilligemed Særmarken Pulkholm i Stendet Østerskov og 2 Gaarde i Langkjær til Kong Frederilk II. for 3250 R(ll. **)

Bjærndrupgaard i Stepping Sogn ejedes 1587 af Kjerstina Ulfeld, Enke efter Morten Svendsen Orning, Lensmand paa Koldinghus. Hum havde maaske arvet den efter $\sin$ første Ægtefæelle Povl Abildgaard til Vranderup, der baade paa fædrene og mødrene Side var fra Sønderjylland. Den solgtes af hende til Kongen den 24. Decbr. 1587. Godset bestod af Hovedgaarden med 1 Mglle, 1 Smedje og 3 Bol paa Gaardens Mark, 1 Gaard i Stepping, 1 G. i Bjært, 2 G. i Skartved og 3 Gadehuse sammesteds, wamt 2 Gaarde og 1 Bol i Kastvraa.

Samme Aar kjobtes af Frederik Husfoged $2 \mathrm{G}$. og 4 Kaad i Lunding, 1 G.. i Vandling, 1 G. og 4 Kaad i Bøgeskov. Om denne Handel kan intet nærmere oplyses.

Tornumgaard i Lintrup Sogn ejedes af Magister. Gunde L ange, der døde 1546 og havde været Erkedegn i Ribe. Den arvedes siden af Frederik Lange til Marke. Han var en Søn af Mag. Gundes Brodersøn Gunde Lange til Breininge og Karen Breide fra Vargaaid. 1577

*) Tysk Skøde, Haderslev d. 3./12 80. Top. Saml. paa Perg.

stik) Tysk Skgde dat. Haderslev d. 12./12 87. Top. Saml. paa Perg. 
forlenedes han med Tonsberg Len og ejede desuden Sofde og Falkensten. Han var gift med Dorthea Lindenov fra Drenderup. Den 11. Novbr. 1587 solgte han Gaird og (rods til Kongen. Det bestod af Thornumgaard, hans Hovedgaard og end $6 \mathrm{Bol}$, der have deres Brug af Gaardens Ejendom, 6 Gaarde og 9 Beskyttelsesfolk i Thornumby og Særmækket-Engum, 1 G. i Kastbjærg, 2 G. i Mejlby, 2 G. i Lintrup, 1 G. i Skolling, 1 G. i Fedsted og 1 G. i Benborg. *)

Bjerningrød Gaard i Bjerning Sogn ejedes 1588 af Morits v. Ahlefeld Godskes Son. Den 12. Jamnar d. n. A. solgte han den til Kongen. Forulen Hovedgaartlen hørte "efternærnte Fæstere" til Godset: 1 G. i Simmersted, 1 G. i Haderslev Bramdrup, 1 G. i Hvinderup, 1 G. i Aller, 1 G. i Braabæek og 1 G. i Skovbglling. ${ }^{*}$ ) Omkring Gaarden findes endnu Spor aí Volde og Grave.

\section{Hejls Vargaard og Breidernes Gods. Breiderne} var en gammel holstensk $\mathbb{E}$ t, som nævnes allerede i det 13de Aarhundrede. Senere bredte den sig til Sonderjylland og Danmark med stor Kraft, men uddøde omkring 1660. Hvorledes Familien er kommen i Besiddelse af Hejls Vargaard kan ikke oplyses. Stamfaderen til denne Gren af Slægten var Hartvig Breide, der 1466 paa Grund af Sørøveri afskedigedes som Amtmand i Svabsted. Senere havde han en af det slesvigske Domkinitels Ejendomme, Gammelby i Angel, i Brug og levede endunu 1510. Hans Søn, Hans Breide, gift med Thale Emmiks-

*) Top. Saml. paa Perg. Dausk Skode paa haus Gods i „Sønder-Juttland“.

(ton) Top. Saml, paa Perg. Tysk Slgqde. 
dattei, ejede Hejls Vargaard (1481 og 1517), og deres Søn Jo a chim Breide, gift med Emmerentze Emmiksen Eriksdatter, efter dem. Ved hans Død 1574 splittedes Godset paa mange Hænder, i det han efterlod sig Sønnerne Hans, Christoffer, Wulf og Frederik samt Døtrene Margrethe (gift med ovennævnte Peder Iversen (Baden) til Fritsø), Karen, Barbara, Anne, Dorthea og Thale; og som vanligt havde (lisse Søskende delt Godset imellem sig. I Aarene 1587 og 1588 kjøbte Kongen Godset. Den 4de Novbr. 1587 solgte Frederik, Dorthea og Thale deres Parter for 14,000 Rdl. og '200 Rdl. for "Atterstaden“; den 28. Febr'. 1688 afhændede Wulf, Anne og Karen deres Andele for sanme Sum, og den 5te Marts 1588 solgte Hans, Christoffer og Barbara Resten med selve Hovedgaarden Vargaard for 17,500 "enskilde gamle Daler." Hele Godset kostede saaledes omtrent 46,000 Rdl. og det bestod af følgende Gaarde og Enemærker: I Hejls 4 G., i Veistruprød 1 G. og 1 Kaad, i Grønninghoved 3 G. og 1 K. og en Særmarkskov, i Mæng 1 G. og 1 Skov, i Skoverup 2 G., 1 Landbol og 1 Skov, i Aller 1 G., i Errigsted 2 G. og 5 Huse, i Anslet 5 G., i Knud 1 G., i Fjelstrup 3 G., i Favrvraa 2 G. og 1 Skov, i Hjerndrup 1 G. og en Særmark Iversbygge, i Frørup 3 G. og 1 Særmark (Risbyholm), i Simmersted 2 G. i Magstrup 2 G.; Jegerup 1 G., i Nustrup Bæk 4 G., i Aabølling 1 G. (der giver $6 \mathrm{Td}$. saltet Fisk og dermed er kvit for alt Arbejde). Desuden solgte de udenfor Amtet 6 G. og 2 Kaad i Skjelle, Gammelgab; Smøled, Sejerslev og Tinglev; i alt 45 G. og 10 mindre Ejendomme.

Af dette Gods havde de en aarlig Skatteindtægt paa 847 Mk. 7 Sk., der fremlrom paa folgende Maade. I 
Penge: 116 Mk. .5 Sk. Af 155 Ørtug Korn (Rug, Mel, Byg og Havre) ì $3 \mathrm{Mk}$. i Gennemsnit: $465 \mathrm{Mlk}$. 33/2 Føle-

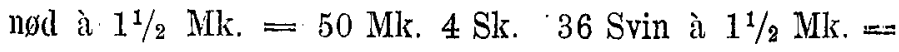
$54 \mathrm{Mk} .15 \mathrm{Faar} \mathrm{à} 1 \mathrm{Mk}=15 \mathrm{Mk} .2 \mathrm{Lam}$ à $8 \mathrm{Sk} .=$ $1 \mathrm{Mk}$., 14 Gæs à $6 \mathrm{Sk} .=5 \mathrm{Mk} .4 \mathrm{Sk} . \quad 38 \mathrm{Høns}$ à $1 \mathrm{Sk}$. $=.2 \mathrm{Mk} .6 \mathrm{Sk} . \quad 2^{1 / 2} \mathrm{Td}$. Smør à $24 \mathrm{Mk} .=60 \mathrm{Mk}$. 6 Trl. Fisk à 2 Mk. $=12$ Mk. 265 Læs Ved à 4 Sk. $=65 \mathrm{Mk}$. 4. Sk. - Desuden kunde der i Godsets Skove fedes 1128 $1 / 2$ Svin, hvoraf Herskabet hvert 5te Aar, „naar fuld Olden er" ${ }^{\prime}, \operatorname{tog} 15$ Sk. pr. Styk eller 3 Sk. hvert Aar, hvilket gav $211 \mathrm{Mk} .13^{1 / 2}$ Sk., og hele Godsindtægten var saaledes 1059 Mk. $4 \frac{1}{2}$ Sk.

Selve Vargatrd med Ladegaarden overdroges til Kongen efter Vurdering af Albret Friis, Høvedsmand par Riberhus og Caspar Markdaner paa Koldinghus og - udenfor den nævite Kjøblesum - skulde han betale Breiderne for Bygningerne efter denne Vurdering samt erstatte dem Udsæden af Rug. 'Til Vargaard saaedes aarlig $22^{1 / 2} \mathrm{Td}$. Rug; $15 \mathrm{Tdr}$. Byg, 50 Tdr. Havre og 6 Ørtug (15 Tdr.?) Boghvede, og der avledes 250 Læs Hø. Skoven, der ligger omkring „Huset“, er god, den bestaar af Ege og Bøge og kan fede 650 Svin.")

Enduu kan der tilføjes, at ovennævnte Frederik Breides Sønner Jakob og Bendix Breide, der boede i Haderslev, 1641 den 1 . April solgte 1. Gaard i Bjært til Kong Christian d. fjerde for "2000 Thl. in Specie“, **)

Efter Frederik II.'s Død 1588 fortsatte Formynderregeringen og Christian IV. Opkjøbet af Adelsgods i Haderslev Amt. 1592 kjøbtes en Gaard i Frørup af Herman Kaas,

*) Top. Saml. paa Perg. - Indkomne Breve til Dansks Kancelli. 1585-1592. Dansk Adelsaarbog. 1888.

*iv) Top. Saml, paa Perg. 
og ved Mageskifte, dateret Flensbor'g d. 1ste Juni 1592, erhvervedes 2 Gaarde og 2 Kaad i Halk af Henrik Rantzau Povelsön paa Lindeved, cler til Vẹderlag fik 3 Gaarde i Sundeved.*) Den 26de April 1593 afstod Hans Blome til Sehedor'f og Nenerstorf 2 G. og 1 Kaad i Hejsager og 2 Gaarde i Emdrup i Hvidding Herred og modtog til Gjengjæld 3 Gaarde og 1 .Kaad i Gammelgab, Skjelle og' Smøled (Breiderne Gods). ${ }^{* *}$ )

'Rødd ingga ar'd val' en gammel adelig Gaard; 1440 nævnes Niels Mortensen Dymeke i Rødding, der vel forte Slkjold, men dog ikke i samtidige Breve henregnes til Væbnerne. Samme Aar nævnes Væbneren Søren Knudsen i Rødding, hvis Vaaben var et delt Skjold, med en halv Lillie i første, et Oxehoved i andet F'elt. Han havde to Sønner, Claus og Innud Sörensen, hvilken sidste ligeledes efterlod sig to Sønner, Søren Knudsen og Henrik Knudsen, der begge skrives til Rødding. Sidstnævntes Søn Henrik Knudsen skrives 1561 til Rødding, men flyttede siden med sin Hustru Anne Gertsclatter til Billum, hvor han endnu boede 1580. Rødding gik da over i Enevold Woi e's Besiddelse. Denne, en bagpommersk.Adelsmand, der skrev sig til Hohenpudiger og var gift med Fru Catharine Rantzaus Datter, var Befalingsmand paa Haderslev Hus og Amtmand i Haderslev mellem 1581-90. Hans Datter Sophie Woie blev gift med Knud Gabrielsen til Hjulerød i Skaane. $\left.{ }^{* * *}\right) 1595$ solgte En evold Wo i e Røddinggaard og Gods til Formynderregeringen. Godset bestod af 3 Gaarde

") Permutationsbrev, Flensborg, 1. Juni 1592. Top. Saml. paa Perg.

*4) Mageskiftebrev, dat. 26. April 1593. Top. Saml, paa Perg. *w*) Optegnelser af Rostgaard. 
og 2 Kaad i Kalvslund, 1 G. i Hjortlund, 2 Kaad i Hjortvad, 1 G. i Meilby; 1 G. i Hygum, 11 G. og 4 Kaad i Rødding, samt „Sønke“ Mølle, der giver 11 Ørtug Rug. Endviciere lijøbte Kongen i Januar 1602 af Christoffer v. Buchwald $\left.{ }^{*}\right)$ par Gram en hel Gaard ( $1 \frac{1 / 2}{2}$ Otting. Jord) i Rødding for 1100 Rdl. Gaarden skyldte $3 \mathrm{Mk}$. lybsk, 1 Daler for 1 Fødenød, 1 Daler for 1 Svin, 1/2 Daler for 1 Faar, 4 Sk. for 1 Gaas, 2 Sk. for Høns og $8 \frac{1}{2}$ Rdl. i Arbejdspenge. Den har Skov til 24 Oldensvin, naar fuld Olden er.

Af Thomas Maltesen Sehested ${ }^{* *}$ ) kjøbte han 1. 20de Novbr. 16032 Gaarde (1 i Hjerting og 1 i Mejlby) af dennes "Arvegods i Sønderjylland".

Taabdrupgaad (Taaggerup) i Stepping Sogn tilhørte i Begyndelse af det 16de Aarhundrede Familien Munk (med 3 røde Roser i Sølvfelt og par Hjelmen 13 rexelvis røde og hvide Faner). Peder Munk til Krogsgaard (i Skads Herred, Ribe Amt) var gift med Mette Emmiksdatter (en Datter af Esbern Emmiksen og Dorthe Breide af Refsø), og det kan tænkes, at hun har bragt Gaarden til Familien. Af deres Børn var Lene Munk gift aned Claus Pedersen (Hundermark?) til Limnet-Hovgaard, der senere skal omtales, og deres Søn Hans Munk til Krogsgaard havde Sønnerne Christoffer Munk, der fik Krogsgnard efter Forælldene, og Christiern Munk til Taabdrup og Hammergaard i Hedemarken. Han var Befalingsmand sxavel paa Agershus som i Trondhjem og

*) Kjøbebrer dat. Tiel 7.-13. Jan. 1602. Frøs Herred. Top. Saml. paa Perg.

$*$ S) Sisødebrev dat. Haderslev d. 20./11, 1603, Orig. pan Perg. Kalvslund Herred. Top. Saml. 
dxde 1579 som Lensmand over Aakjær i Jylland. Hans: Datter Else Munk blev gift med Christoffer v. Ger'sdorff til Sæbygaard, Hofjunker og Kjøgemester, der ved Mageskifte af 18de Decbr. 1604 afhændede Taabdrup til Kong Christian VI. Mod at faa Lønborg Bispegard paa Livstid afstod han sin "Hustrus Arvegods i Sønderjylland, som er først vor Hovedgaard Thaaberup med dens tilliggende Ejendom, Skove, Enemærker og al anden. Herlighed og Rettighed intet undentaget", og dernæst følgende Bøndergods: 1 Gaard og 1 Bol i Stepping, 3 G. og 1 Bol i Halk (der have Olden til 50 Svin) og 1 G. i Raade. I Hviddingherred i Aabølling $2 \mathrm{Bol}$ (med en Skyld. af $4 \mathrm{og} 3 \mathrm{Rdl}$. Pendinge), $1 \mathrm{Bol}$ (4 Rdl. 1 Ørt.) i Vestervedsted og 1 Gaard $i$ Hillerup i Farup Sogn.*)

Den 26de Juni 1613 solgte Kjeld Brockenhus til Lerbæk nogle Ejendomme i Thyrstrup Herred til Kongen, nemlig 1 Gaard i Favstrup (der skylder 14 Mk. lybsk, 15 Skpr. Havre,-1. Svin, 1 Daler Gjæsteri), 1 Gaard $\mathbf{i}$ Hvinderup (Hunderup?), 1 Femtedel af 1 G. i Ajtrup, 1 Femtedel af 2 Kaad i Ajtrup og af 1 i „Biardt". „Disse 3 Kaad have saavel Tov i Marken som Lod i Skoven." Salgsprisen angives ikke. Det turde maaske formodes, at dette Gods oprindelig har hørt til Bengaard i Bjært Sogn, og at det er kommet paa Kjeld Brockenhus's Hænder ved den Proces, som hans Svigermoder Jost Andersen Ulfelds Enke 1577 anlagde imod Tønnies Rantzau paa Vilstrup Gaard, der dengang endnu var i Besiddelse af noget Gods under-Bengaard. ${ }^{* *}$ ) Og fra samme Kilde slkulde

m) Skøder Nr. 103. Begtrups Afhandling' om Familien Mank. Biogr. Tidsskr. 1840.

**) Annal. Nord. Oldlkyndigher, 1853. S, 79. Slsøde paa Perg. Slesvig 198. 
sla ogsaa det Gods hidrøre, som Johan Brockenluus, Ijelds Søn, solgte Kongen i Februar 1635, nemlig 1 Gaard i Ajtrup (der har Skov til 24 Svin), 2 Mæuld i samme By, der aarlig skylder hver $2: 2 / 2$ slette Mark og 1 Mand i Bjært, der staar for samme Skyld. ${ }^{*}$ )

Linnetgaard eller Linnet-Hovgard i Østerlimnet Sogn ejedes i Slutningen af Middelalderen af en Familie, hvis Vaaben var' en Murtinding, ligesom Hundermark'ernes. Af Ejeme næves Nicolaus Jensęn de Linvyt 1439 , Sønnen Peder Nielsøn 1479 og demnes Sønner Jens, Thomes og Claus Pedersøn, der var gift med den Dvenfor (under Trabdrup) nævnte Lene Munk af Krogsgaard. (Disses Farbroderson Th o mas Eriksen skrev sig 1479 ligeledes til Linnet.) Deres Datter Kirsten blev gift med Jørgen Pedersøn og bragte ham Gaarden. Iran, der skrives til Linnetgand allerede $1525,{ }^{* *}$ ) var en Søn af den fynske Adelsmand Peder Eriksen til Veistrup og Dorte Ottesdatter Hogenskild og førte i sit Vaaben en halv Ulv og en halv Ørn. Han vides ikke at have efterladt sig Børn, lige saalidt som hans Hustrus to Fættere Peder og. Jens Thomesen, der endnu nævnes 1519. Fru Lone Munk har formodentlig overlevet hele sin Husbonds Slægt og arvet Linnet efter sin Datter, hvorved Gaarden er kommen til Munk'erne.

Den 18de Juni 1602 selgte Marine Munk, salig Lange Hvitfeldts Efterleverske, der var en Brodersons Datter af Fru Lene Munk, til sin kjære Farbroders Søn

*) Skøde paa Perg. Dat. Kolding d. 13. Febr. 1635. Top. Saml. paa Perg.

960) Dansk Magaz. 4 R. 3 B. S. 237. De der meddelte Oplysninger om .Jsrgen $P$, ere aldeles urigtige. 
Frederik Munk til Krogsgard alt sit „Jordegods og Ejendom udi Sønderjylland liggendes som efter mine salige Forældre mig arveligen er tilfalden," nemlig L.innetgaard i Østerlinnet Sogn, 4 Bol i Østerlinnet By, der skylder hver 1 Daler, og 1 Gaard i Sønder-Fardrup. By, der skylder 8 Daler. Men allerede d. 31te Juli s. A. kjøbte Frederik Munk 9 Gaarde og 10 Bol i Østerlinnet By af Christoffer v. Buchwaldt paa Gram, org den 6te April 1614 skøder saa samme Frederik Munk til Krogsgaard Linnet-Hovgaard med sine tilliggende Bole etc. og "alle hues Gaarde och Landboele som ieg aff salig affgangne Christ. v. Buchwaldt til Gran kiøbt haver" - til Kong Ghr. IV. Salgsprisen anføres ikke. *)

Tyrstrup Gaard i Tyrstrup Sogn tilhørte i det 15de og 16de Aarhundrede Familien Emmiksen. 1491 ejedes den af Barbara von der Wisch, Erik Emmiksens Enke, senere af Claus Emmiksen $(\dagger$ 1541) og sammyes Sønner Erik, der blev dræbt 1554 paa Vejen i Nærheden af Sønder Løgum af en Borger fra Tønder ved Nødværge, da han overfaldt denne, og Markvard Emmiksen, der var gift med Abel Tegenhus fra Tvedsgaarl, men ej havde Børn. Derefter kom Gaarden ved Giftermaal til Henrik v. Ahlefeldt af Königsföhrde ( $†$ 1583), og dennes Søn Goske v. Ahlefeldt, der 1599 solgte Gaarden til Gert Rantzau til Breidenberg, Amtmand i Haderslev og Statholder i Hertugdømmerne; den kostede 18,500 Rdl.* Ved Mageskifte af 9de Febr. 1617 overdrog Statholderen

*) Top. Saml. paa Perg. Frø Herred.

***) Jahrb. X. S. 196. - 1613 havde Gert Rantzau kjøbt Høgsbrogaard for 7000 Rdl. og Vesterbæk for 7200 Rdl. Begge i Tørninglen. 
saa Gaarden til Kongen imod at faa andet Gods i Rendsborg Amt (eigen Bundenguter), i Flensborg, Aabenraa og Tønder Amt samt i Løherred under Trøjborg. Men desuden forpligter Kongen sig til at yde en arlig Livrente par $450 \mathrm{Rdl} . \mathrm{og}$ at betale $8000 \mathrm{Rdl}$. ved Omslaget i Kiel 1617. I Permutationsbrevet skuiver Kongen, at han har foretaget dette Magelæg „for at forbedre vort Amt Haderslev ${ }^{*}$ ) og den deri liggende Vildbane." Han modtog til Gjengjold: Tyrstrup Hovedgard med en stor Mongde Kobler og Marker, der alle opregnes i Mageskifts-Dokumentet samt Gaardens Skove til 279 Svins Olden. Endvidere 5 Gaarde, 7 Landbol og 3 Gadehuse i Tyrstrup By, Tyrstrup Mølle og en lille Mølle sanmesteds, der begge give 22 Ørt. Mel, 1 G. i Bøgeskov, 1 Landbol i Favstrup, 4 G. og 3 Landbol og Gadehuse i Bjarndrup, 1 G. i Rørkjær, 3 G. i Frørup. I Aller Sogn i Skovhuse: 3 Gaardmænd, 2 Landbol og 1 Hus (og give alle Skovhuse Mænd af Skovhuse Enemærke tilsammen 1 Tønde Snør), 2 G. i Nustrup, 1 Hus i Skrydstrup, 2 G. og 1 Landbol i Jegerup (og er Jegerup Skov af forne to Gaardmænd taxerid for 6 Svins Olden), 1 G. i Ringtved, 3 G. og 3 Landbol i Raade, 1 G. og 1 I tandbol i Stevelt, 1 G. i Hajstrup.

Gjelst oft var tidligere en Landsby under Gram og Tovskov. Ved Kjøbet af Tovskov liavde Frederik II. erhvervet 3 Gaarde i Byen, og den 24de Novbr. 1638 kjøbte Kong Christian IV. af Detlev v. Buchwaldt til Nybøl far en Kjøbesum af 5650 Rdl. følgende Gaarde og Landbol: 3 Gaarde, der kaldes Gjelstoft, og som Hans Jessen

*) Trykt i Danske Magaz. 1747. IV. B. S. 112. Hele Mageskifteakten: Slesv. Nr. 203. 
og Peder Jessen nu udi Hyre have og give deraf anrlig 287 Rdl. 40 Sk. lybsk; 1 halv Gaard i Arnum og .9 Landbol i samme By. ${ }^{*}$ )

Ved alle disse Mageskifter og Kjøb i Tidsrummet mellem 1500 og 1641, men særlig dog i Kong Frecierils II.s 'Tid, havde Kronen lagt ca. 690 Bøndergaarde, Møller og Hovedgaarde samt mæsten 300 Landbol og andre mindre Ejenclomme, eller i alt paa det nærmeste 1000 Familiesteder ind under Amtet, ja, hvis vi regnede Torning Gods med, vilde dette Antal maaske entogsaa kunne fordobles. Selvfølgelig maatte dette have en indgribende Betydning paa Amtets Karakter og hele fremtidige Udvilking, men hertil kom, at Udkjøbet fandt Sted netop pąa et meget kritisk Tidspunkt $\mathrm{i}$ vor Landboudvikling, uniddelbart for Indførelsen af den moderne Godsdrift med ublu Hoveri og Trældom. For disse trykkende Byrder forskanedes Befolkningen i hvert Fald tildels; i Stedet for mange smaa fik den én mægtig Herre; der kom Ensartethed og Lighed ind i Amtet, idet de nye Fæstere fiskalt og retsligt stilledes lige med de ældre Amtsbgnder og sammen med dem maatte bære det Hoveri, som Regeringen paalagde dem. Da Kong Frederik II. var kommen i Besiddelse af de fleste store Hovedgaarde, grupperede han Amtets Befolkning som "Tjenere" omkring disse og lod Gaardene drive ved cleres Arbejde. Derfor rensede han ikke alene Sadegaardenes Hovmarker for Fæstere, men lian nedlagde og afbrød endogsaa 'forskjellige Byer' for at forstørre disse Hovmarker eller skabe nye Ladegaarde. Denne Skæbne traf saaledes Fovslet By, hvis Jorder lagdes ind under Fovslet Gaard,

") Top. Saml. paa Perg. 
Stendet By i Aastrup Sogn, der lagdes under Haderslev Ladegaard, og Vojens (Vodens, Vuens) i Jegerup Sogn, der endnu 1580 bestod af 11 Gaarde, men un omdannedes til en kgl. Ladegaard. *) I noget over en Menneskealder gjorde Bønderne i Haderslev Amt Hoveri til alle disse Gaarde, til Tørning, Vojens, Harlerslev Ladegaard, Vargaard, Fovslet, Drenderup, Refsö, Røddinggaard osv., men dette Forsøg paa Godsdrift i stor Stil synes ilkke at have svaret sig, i hvert Fald begyndte Regeringen allerede i Begyndelsen af det 1\%. Aarhundrede enkeltvis at bortforpagte Gaardene og omsætte Bøndernes Arbejde i en Pengeafgift, og omkring Aar 1633 synes der at være truffet en endelig Ordning af dette Forhold, idet Amtmand Georg v: Ahlefeldt (til Quarnbeck) og 24 Mæud af hvert Herred taxerede Bøndernes Spandtjeneste og paalagde dem i Steden for demne - enhver efter "aduenmut" eller Sædvane - en fast aarlig Skat, de saakaldte Fripenge. Kun et hojst ubetydeligt. Hoveri, som oftest en enkelt „Gangdag" om Aaret, holdt sig indtil Domænegaardenes Udparcellering i forrige Aarhundrede eller endnu længere.

*) Alle disse tre Byer ere forsvundne mellem I580 og 1595, og naar det almindelig fortælles, at Vojensby ødelagdes $i$ Svenskekrigen 1658-60, er dette nden al Hjemmel. For et Pal Aar siden har Hr. Kjøbm. Schmidt $i$ Vojens fundet den gamle Bytomt nogle tusinde Alen Sydvest for Vojensgaard. - Her kan endnu tilføjes, at Kongen ved Mageskifte 1602 lagde Aarø ind under Amtet. Øen havde tidligere hørt til Bispegodset Svabsted. 1603 faldt ligeledes en Del Gods, som en vis Jacob Høyer havde været benaadet med, tilbage til Amtet, nemlig 1 G. i Raade, 1 i Halk, 3 i Hejsager, 1 i Brorsbøl, 1 i Vandling, 1 i IJjærstrup, 1 i Moltrup, 1 i Ørby, 1 i Aastorp, 1 i Anslet, 1 i Fjelstrup og 1 i Knud. Af den skanuske Adelsmand Iver Uldsax $1 \mathrm{G}$. i Sod og 1 i Ilejsager. 